\title{
Membangun Kapasitas Petani Lahan Marjinal di Perbatasan Darat Indonesia (Kasus di Belu, Nusa Tenggara Timur)
}

\section{Building Capacity of Marginal Land Farmer's in Indonesian Cross Border (Cases in Belu District, East Nusa Tenggara)}

\author{
Budi Sawitri ${ }^{1}$, Siti Amanah ${ }^{2}$, Amiruddin Saleh $^{3}$, Aida Vitayala S. Hubeis ${ }^{4}$ \\ ${ }^{1}$ Program Studi Penyuluhan Pertanian Berkelanjutan, Politeknik Pembangunan \\ Pertanian Malang; Jalan Dr. Cipto 144 A Bedali Lawang Malang, Jawa Timur, 65200 \\ ${ }^{2,3,4}$ Departement of Communication Science and Community Development, Faculty of \\ Human Ecology, IPB University, Dramaga, Bogor, West Java, 16680 \\ e-mail: ${ }^{1}$ budisawitri@polbangtanmalang.ac.id
}

\begin{abstract}
ABSTRAK
Perbatasan negara merupakan garda terdepan dalam upaya menghadapi dampak integrasi terhadap negara tetangga. Kondisi keberagaman biofisik dan sosial yang tinggi menjadi salah satu permasalahan dalam upaya pembangunan sehingga diperlukan pendekatan pembangunan yang tepat, terutama di bidang pertanian. Tulisan ini bertujuan untuk menggambarkan potensi, kondisi kesejahteraan petani dan sumber daya manusia, dan kebijakan pembangunan pertanian. Studi literatur digunakan untuk membahas gambaran wilayah perbatasan dengan didukung data dan hasil penelitian yang relevan. Hasil studi menunjukkan bahwa peranan sumberdaya manusia dalam pembangunan pertanian sangat penting, sehingga diperlukan penguatan kapasitas petani dalam mengembangkan potensi pertanian di perbatasan negara yang memiliki keragaman biofisik.
\end{abstract}

Kata kunci- kapasitas, lahan marginal, perbatasan negara

\begin{abstract}
State borders are the frontline in the effort to face the impact of integration on neighboring countries. The condition of high biophysical and social diversity is one of the problems in the development effort so that an appropriate development approach is needed, especially in agriculture. This paper aims to describe the potential, the welfare conditions of farmers and human resources, and agricultural development policies. A literature study is used to discuss the description of the border area supported by relevant data and research results. The results of the study show that the role of human resources in agricultural development is very important, so it is necessary to strengthen the capacity of farmers to develop agricultural potential in national borders that have biophysical diversity.
\end{abstract}

Keywords - capacity, marginal land, national borders

8 | Jurnal Agriekstensia Vol. 19 No. 1 Juli 2020 


\section{PENDAHULUAN}

Indonesia merupakan negara yang memiliki kawasan perbatasan serta berhadapan langsung dengan negara tetangga seperti Malaysia, Singapura, Filipina, Papua Nugini dan Timor Leste. Kondisi ini menurut Saragih (2017) seharusnya menjadi garda terdepan dalam menghadapi dampak integrasi dengan negara tetangga, namun faktanya menurut Saleh (2015) posisi masyarakat perbatasan yang berada di pinggiran dan menjadi kelompok pinggiran (marginal) menjadi sangat dinamis dalam berinteraksi terutama dengan masyarakat negara tetangga.

Masyarakat perbatasan cenderung masuk dalam kelompok masyarakat tertinggal yang memiliki masalah umum seperti lokasi relatif terpencil dan terisolir, rendahnya tingkat pendidikan dan kesehatan, tingkat kesejahteraan sosial ekonomi, dan keterbatasan sarana dan prasarana (Prasojo 2013; Priyanto dan Diwyanto 2014; Saleh 2015; Saragih 2017). Kondisi ini menyebabkan wilayah perbatasan rentan tertinggal dari berbagai aspek pembangunan di Indonesia. Padahal perbatasan merupakan entry point hubungan bilateral antar negara.

Dalam upaya membangun pertanian di kawasan perbatasan diperlukan pendekatan yang tepat, berimbang, dan terprogram (Priyanto dan Diwyanto 2014). Hal ini dikarenakan wilayah perbatasan memiliki keragaman biofisik dan sosial yang tinggi. Keragaman biofisik sesungguhnya merupakan potensi yang besar bila dimanfaatkan secara terarah dan optimal. Pembangunan pertanian di wilayah perbatasan hendaknya bersifat spesifik lokasi yang disesuaikan dengan lokasi pembangunan (Jaya 2017; Priyanto dan
Diwyanto 2014). Namun permasalahan sumberdaya manusia yang rendah menyebabkan pembangunan pertanian di wilayah perbatasan menjadi terhambat. Terkhusus pada wilayah perbatasan darat Indonesia dan Timor Leste, salah satunya adalah Kabupaten Belu. Pembangunan pertanian di wilayah ini diarahkan untuk meningkatkan taraf hidup dan kesejahteraan masyarakat, dimana pilihan dan pengembangan komoditas disesuaikan dengan kondisi ekosistem (kondisi dan kendala alam dan lahan). Tantangan pengembangan pertanian yang menguntungkan dan berkelanjutan harus didukung oleh lingkungan sistem sosial di wilayah perbatasan. Tulisan ini mencoba menggali konsep pentingnya membangun kapasitas petani dalam mengembangkan potensi pertanian di wilayah perbatasan darat Indonesia khususnya di Kabupaten Belu, Nusa Tenggara Timur, yang merujuk dari gambaran potensi, kondisi kesejahteraan petani dan sumber daya manusia, serta kebijakan pembangunan pertanian di wilayah perbatasan.

\section{POTENSI PENGEMBANGAN PERTANIAN}

Tanah dan lahan di Kabupaten Belu Nusa Tenggara Timur dicirikan dengan tekstur sedang dan sebagian kecil bertekstur tanah halus dan kasar atau sering disebut tanah aluvial. Pada umumnya jenis tanah ini memiliki tingkat kesuburan yang tinggi karena kaya akan unsur hara. Luas lahan sawah 7.373 hektar dengan sebaran sawah tadah hujan $2 \%$ sedangkan irigasi teknis sekitar 4\%. Lahan kering di wilayah ini yang sangat dominan adalah lahan kering yang mencapai $15 \%$ dari luas keseluruhan wilayah Kabupaten Belu (BPS 2017). Lebih rinci dapat dilihat pada Gambar 1. 


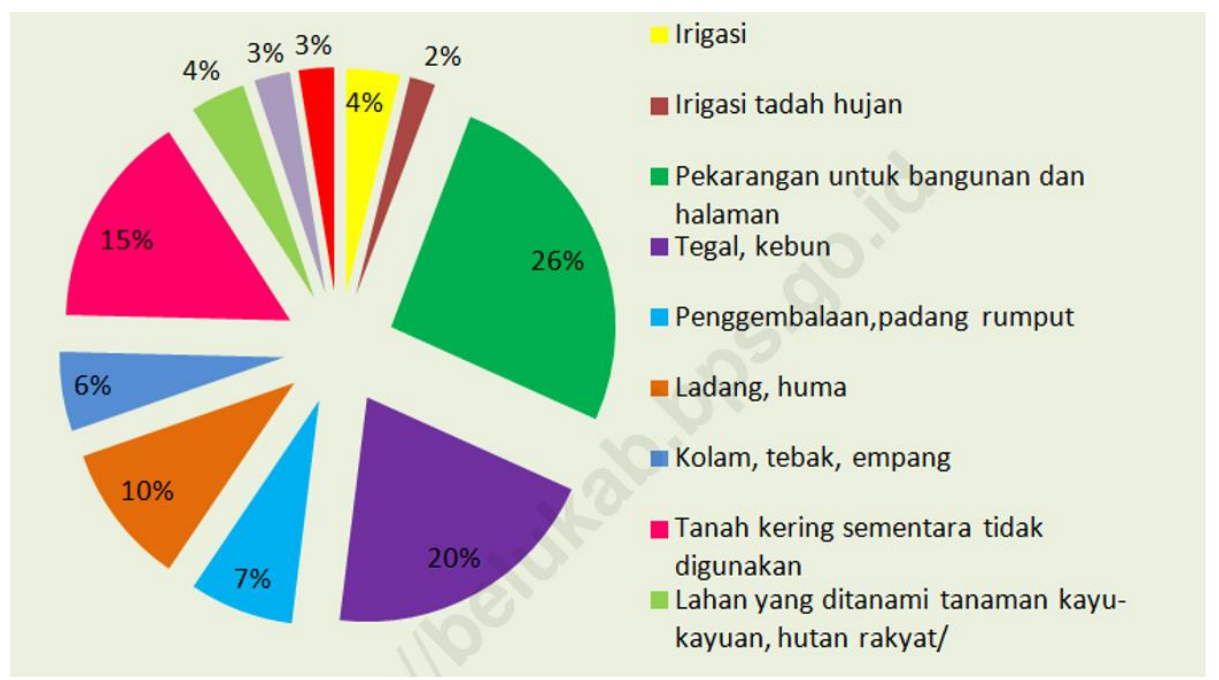

Gambar 1. Persentase luas tanah menurut penggunaan di Kabupaten Belu, 2016 (BPS 2017)

Mengacu pada kondisi lahan di Belu, pembangunan pertanian tidak mungkin bertumpu pada lahan sawah saja, lahan kering juga memiliki potensi ekosistem yang menjadi peluang pengembangan pertanian (Dariah dan Las 2010; Priyanto dan Diwyanto 2014). Selain berpotensi untuk produksi jagung, kacang-kacangan dan ubi jalar, lahan kering juga berpotensi untuk pengembangan padi gogo, sehingga menurut Priyanto dan Diwyanto (2014) lahan kering direkomendasikan untuk meningkatkan produksi padi maupun tanaman pangan lainnya.

\section{KESEJAHTERAAN PETANI}

Kesejahteraan petani merupakan sasaran akhir dari pembangunan pertanian. Petani sebagai pelaku utama dalam pembangunan pertanian sudah selayaknya mendapatkan hak sepadan sesuai dengan curahan waktu, tenaga dan pikiran dalam bekerja di sektor pertanian. Namun faktanya tingkat kesejateraan petani masih tergolong rendah. BPS (2018) mencatat bahwa tingkat kemiskinan di Indonesia berada pada angka 9,82 persen yaitu mencapai
25,95 juta orang. Persentase penduduk miskin di perkotaan sebesar 7,02 persen dan relatif lebih sedikit daripada di perdesaan yang mencapai 13,20 persen. Peranan komoditi makanan terhadap kemiskinan jauh lebih besar daripada komoditi bukan makanan. Makanan menyumbang sebesar 73,48 persen terhadap kemiskinan yang terjadi di Indonesia. Sementara komoditas makanan yang berpengaruh besar terhadap kemiskinan baik di perkotaan maupun di perdesaan salah satunya adalah beras (sekitar 23,87\%).

Beras merupakan salah satu komoditas pangan dan merupakan kebutuhan esensial bagi kehidupan manusia. Pangan selain sebagai pemenuhan kebutuhan psikologis, juga berkontribusi membentuk sumberdaya manusia sebagai aset pembangunan bangsa dan negara. Pemenuhan kebutuhan pangan bagi warga negara identik dengan hak asasi (UU No 182012 tentang Pangan). Bagi Indonesia upaya memantapkan ketahanan pangan tampaknya menjadi sebuah tantangan seiring laju pertumbuhan penduduk yang terus bertambah dan perubahan iklim yang 
mengancam kemampuan produksi pangan di Indonesia (SKRI 2015).

Sektor pangan merupakan sektor penentu tingkat kesejahteraan petani di Indonesia, karena sebagian besar penduduk bekerja sebagai petani berada di daerah pedesaan, sementara di perkotaan masyarakat lebih banyak menghabiskan penghasilannya untuk memenuhi kebutuhan konsumsi. Untuk memelihara ketahanan nasional, syarat mutlak yang harus dilakukan adalah mewujudkan kemandirian pangan. Jika ketersediaan pangan lebih kecil dibandingkan kebutuhannya akan berdampak pada ketidakstabilan ekonomi, gejolak sosial dan politik. Kondisi pangan yang kritis juga dapat membahayakan stabilitas ekonomi dan nasional.

Saheb et al (2013) menjelaskan bahwa di beberapa negara maju, dua hingga empat persen penduduknya mampu memproduksi makanan untuk seluruh penduduknya bahkan mampu mengekspornya, namun di negara berkembang 60-80 persen penduduk belum mampu memenuhi kebutuhan pangan penduduknya. Kecenderungan penduduk pada negara berkembang masih berorientasi pada pemenuhan kebutuhan pribadi, itupun terkadang belum terpenuhi. Sehingga ketika kebutuhan akan pangan tidak terpenuhi maka ketidakstabilan ekonomi akan terjadi. Irsan et al. 2017 mengatakan bahwa kendala pengembangan perbatasan dalam perspektif ekonomi adalah peran kebijakan dan infrastruktur, sehingga diperlukan strategi pengembangan dengan mendorong regulasi bidang ekonomi dan meningkatkan peran sektor unggulan serta mendorong sektor lainnya.

\section{KEBIJAKAN PERTANIAN \\ PEMBANGUNAN}

Pangan identik dengan beras, dan merujuk dari akar permasalahan kemiskinan di Indonesia adalah beras, maka peran beras sangat penting dalam ketahanan nasional. Menyadari pentingnya arti pangan, pemerintah saat ini menggalakkan program swasembada pangan. Melalui visi yang dinyatakan dalam Rencana Strategis Kementerian Pertanian 2015-2019 yaitu "Terwujudnya sistem pertanianbioindustri berkelanjutan yang menghasilkan beragam pangan sehat dan produk bernilai tambah tinggi berbasis sumberdaya lokal untuk kedaulatan pangan dan kesejahteraan petani", semua kebijakan mengarah pada kesejahteraan petani (Kementan 2015). Peningkatan produksi beras digalakkan pemerintah melalui program Upaya Khusus Peningkatan Produksi Padi Jagung dan Kedelai.

Kondisi ini sangat miris ketika melihat potensi pertanian yang ada di Indonesia. Indonesia adalah salah satu negara agraris yang 70 persen luas daratannya dimanfaatkan untuk usaha pertanian. Pada dasarnya Indonesia memiliki peluang untuk mewujudkan swasembada pangan guna mencapai ketahanan pangan. Dari letak geografis, Indonesia sangat diuntungkan karena terletak di wilayah tropis dan memiliki curah hujan yang cukup. Modal dasar ini setidaknya mampu menjadi kekuatan dalam meningkatkan produksi pertanian. Faktanya, alih fungsi lahan sawah produktif terjadi di Indonesia dan diperparah dengan masih banyaknya jumlah petani gurem $(14,25$ juta rumah tangga pertanian), perubahan iklim, bencana alam, dan kondisi serius lainnya seperti degradasi sumberdaya lahan, air dan lingkungan, meluasnya lahan 
terlantar serta terbatasnya lahan potensial untuk pengembangan pertanian (BPS 2013; BPPSDMP 2018).

Berbagai upaya telah dilakukan baik oleh Badan Nasional Pengelolaan Perbatasan (BNPP) yaitu pembangunan kawasan perbatasan negara melalui program pengembangan sumber daya manusia (generasi muda) kawasan perbatasan. Program ini mengacu pada Undang-undang No 43 tahun 2008 tentang wilayah negara dan Peraturan BNPP no 1 Tahun 2015 tentang Rencana Induk Pengelolaan Perbatasan Negara Tahun 2015-2019. Merujuk pada salah satu arah dan kebijakan pembangunan kawasan perbatasan darat dan laut yaitu meningkatkan kesejahteraan masyarakat dan kegiatan ekonomi lokal di kawasan perbatasan darat dan laut, maka BNPP bersinergi dengan Kementerian Pertanian melalui BPSDMP pada pencapaian strategi peningkatan komoditas unggulan dan ekonomi kerakyatan dan peningkatan kualitas pelayanan pendidikan dan kesehatan.

Upaya pengembangan pertanian oleh kementerian pertanian juga sudah mengarah pada spesifik lokasi yang disesuaikan dengan kondisi dan potensi ekosistem wilayah perbatasan. Berdasarkan programa penyuluhan pertanian Kabupaten Belu, program kegiatan lebih mengarah pada penerapan sistem pertanian terpadu. Hal ini didasarkan pada potensi lahan dan ternak serta potensi komoditas seperti yang direkomendasikan oleh Priyanto dan Diwyanto (2014). Sistem pertanian terpadu merupakan sistem yang menggabungkan kegiatan pertanian, peternakan, perikanan, kehutanan dan ilmu lain yang terkait dengan pertanian dalam satu lahan, sehingga dapat sebagai salah satu solusi alternatif bagi peningkatan produktivitas lahan. Sistem ini menerapkan prinsip zero waste karena limbah peternakan dapat digunakan sebagai pupuk dan limbah pertanian dimanfaatkan untuk pakan ternak dan ikan. Penerapan sistem pertanian terpadu selain dapat meningkatkan usaha petani, juga dapat mendukung pola pertanian organik yang sudah menjadi tuntutan konsumen sesuai dengan kemajuan teknologi (Kementan 2018).

\section{PRODUKSI PRODUKTIVITAS}

DAN

Seperti yang telah dijelaskan sebelumnya bahwa beras merupakan makanan pokok masyarakat Indonesia, tentunya beras merupakan produk potensial untuk dikembangkan di Indonesia. Ironisnya produksi beras nasional belum mengalami kemajuan yang signifikan. Akar masalah dari produksi beras nasional bersumber pada kebijakan-kebijakan pemerintah seperti subsidi pupuk, benih, kredit istimewa dan lain-lain belum berjalan dengan semestinya. Upaya-upaya untuk meningkatkan produksi padi telah banyak dilakukan baik oleh pemerintah, lembaga swadaya masyarakat, dan perguruan tinggi.

Mahananto et al. (2009) mengatakan, kondisi di lapangan menunjukkan bahwa hasil potensial produksi padi berbeda dengan hasil nyata yang diperoleh petani. Perbedaan hasil ini secara garis besar disebabkan oleh dua faktor yaitu faktor teknis dan non teknis (sosial ekonomi). Faktor dominan yang mempengaruhi adalah faktor non teknis diantaranya yaitu keadaan yang menghalangi petani untuk menggunakan teknologi yang direkomendasikan seperti perilaku (pengetahuan, sikap, keterampilan) petani dalam berusahatani. Hal ini menurut Ishaq et al. 
(2017) berdampak pada faktor teknis (kesuburan tanah, curah hujan, kelembaban, penggunaan input, dan sebagainya). Faktor non teknis dan faktor teknis akan mempengaruhi pertimbangan petani dalam pengambilan keputusan penggunaan input (bibit, pupuk, tenaga kerja, dan obat-obatan). Faktor-faktor tersebut bekerja secara simultan sehingga akan mempengaruhi tingkat produksi dan produktivitas padi.

Sementara konsep Indonesia menuju Lumbung Pangan Dunia 2045 menjadi landasan pengembangan padi di semua sektor (Sulaiman et al. 2017) begitu juga di wilayah perbatasan. Dalam konteks pengembangan lumbung pangan dunia berorientasi ekspor untuk wilayah perbatasan dilakukan dengan meningkatkan kapasitas produksi dan daya saing pangan nasional sehingga mampu memanfaatkan peluang ekspor ke pasar negara tetangga dan pasar global. Selain itu juga mengembangkan sistem pertanian modern berbasis kawasan khusus dan inovasi, baik teknologi maupun manajemen dengan memperhatikan berbagai faktor strategis secara holistik (Handayani 2018). Peta penempatan lumbung pangan nasional berorientasi ekspor di wilayah perbatasan dapat dilihat pada Gambar 2.

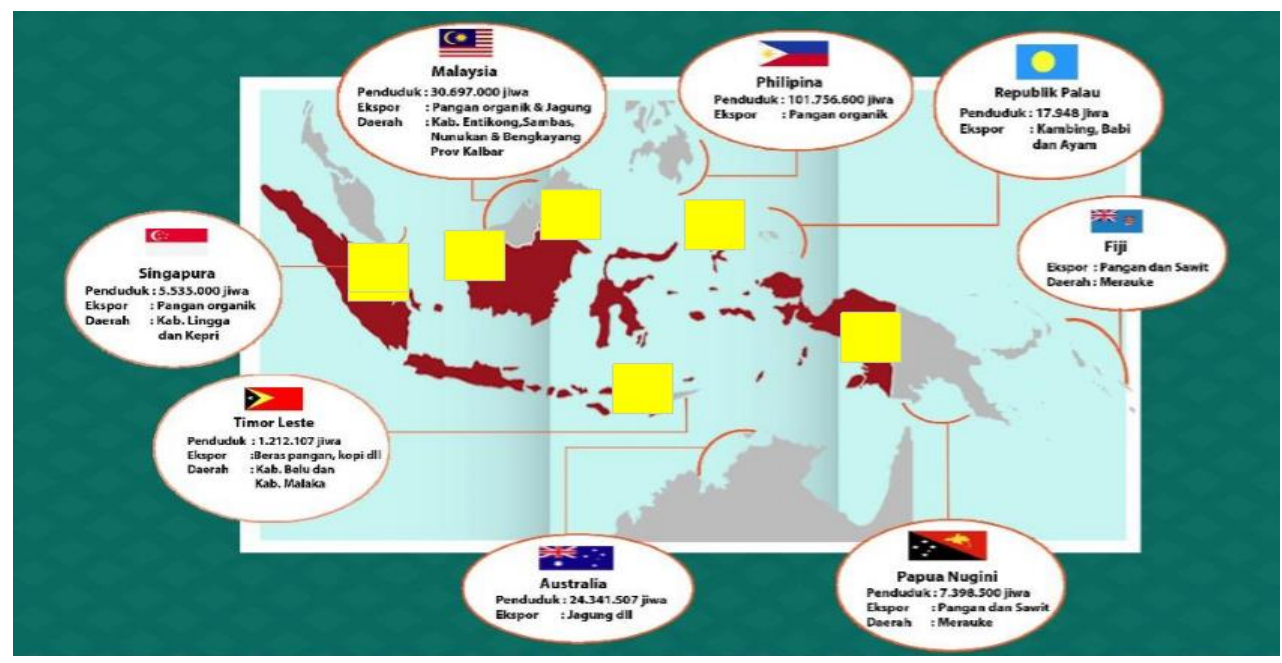

Gambar 2. Peta penempatan lumbung pangan nasional di perbatasan

(Kementerian Pertanian 2018)

\section{KONDISI SUMBER DAYA MANUSIA}

Pembenahan kawasan perbatasan yang gencar dilakukan beberapa tahun terakhir ini seakan memberikan harapan perbaikan hidup warga setempat. Faktanya pembangunan lebih berfokus pada pembenahan infrastruktur dan mengabaikan sumberdaya manusia. Kawasan daerah perbatasan rata-rata dihuni oleh anggota masyarakat yang tergolong ekonomi rendah, jauh dari sejahtera terhadap prioritas pembangunan seperti infrastruktur, pemberdayaan potensi, pelayanan sosial, ekonomi, dan pendidikan masih sangat terbatas. Kemiskinan menyebabkan daya beli masyarakat rendah dan menjadi akar masalah dalam usaha pertanian. Rendahnya akses lahan dan input produksi, lemahnya perilaku petani (pengetahuan, sikap dan keterampilan) menjadi faktor penyebab rendahnya produktivitas pertanian.

Pembangunan suatu bangsa pada dasarnya memerlukan aspek pokok yang 
disebut dengan sumber daya (resources) baik sumber daya alam maupun sumber daya manusia (Saragih et al. 2016). Kedua sumberdaya ini sangat penting dalam menentukan keberhasilan suatu pembangunan. Diperkuat oleh Afrizal (2013) bahwa pembangunan sumber daya manusia harus jelas dan tepat sasaran sehingga memberikan kemanfaatan yang nyata dan dampak positif bagi masyarakat perbatasan.

Pengembangan sumber daya manusia diperlukan untuk mengatasi ketertinggalan sosial ekonomi masyarakat perbatasan. Ketertinggalan ini terlihat dari Indeks Pembangunan Manusia (IPM) di 74 persen dari 134 Kabupaten/Kota di perbatasan yang kondisinya lebih rendah rata-rata IPM Nasional 2015 sebesar 69,55. Ketertinggalan sumberdaya manusia membuat warga perbatasan sulit bersaing dengan pendatang. Seperti misalnya di Motaain NTT, pembangunan Pos Lintas Batas Negara (PLBN) yang diikuti pelebaran jalan menuju batas negara membuat para investor dari luar Kabupaten Belu memborong tanah-tanah warga di tepi jalan, sehingga menyebabkan kesenjangan di masyarakat. Masalah lain terdapat pada pasar Turiskain di Desa Maumutin, yang berjarak 500 meter dari wilayah Timor Leste juga didominasi oleh pedagang dari luar Kabupaten Belu.

\section{PENGUATAN KAPASITAS PETANI}

Dalam pengembangan kapasitas sebagai persyaratan fungsional dan teknik ada tiga tingkatan yaitu individu, organisasi dan tingkat lingkungan atau sistem yang memungkinkan. Tingkat individu, berhubungan dengan pengetahuan, keterampilan (teknis dan manajerial, dan sikap yang dapat diatasi melalui fasilitasi, pelatihan, dan pengembangan kompetensi). Tingkat organisasi, berkaitan dengan organisasi publik, swasta, dan organisasi dalam hal a) fungsi, struktur, dan hubungan manajemen strategis, b) kapasitas operasional (hubungan, proses, sisem, prosedur, sanksi, insentif dan nilai-nilai), c) sumber daya manusia dan keuangan (kebijakan, penyebaran, dan kinerja), d) sumberdaya pengetahuan dan informasi, dan e) infrastuktur. Tingkat lingkungan (sistem), berkaitan dengan komitmen dan visi politik (kerangka kebijakan, hukum), peraturan dan ekonomi (alokasi dan proses anggaran), sektor publik nasional (pemerintahan) dan struktur kekuasaan (peran dan kapasitas individu di tingkat organisasi dan sistem) (Davis dan Sulaiman 2014). Konsep keterkaitan kapasitas, kompetensi dan ability dapat dilihat pada Gambar 3.

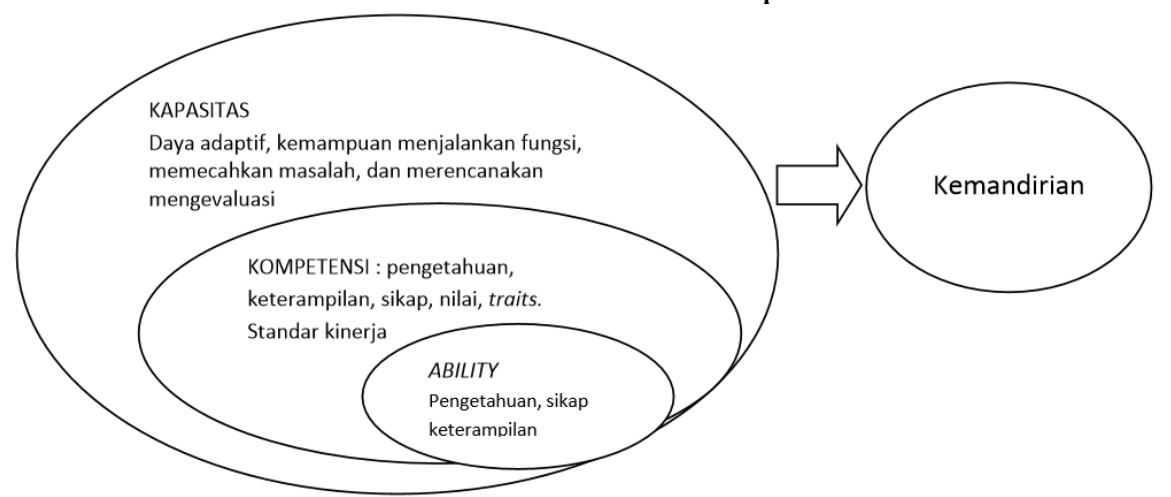

Gambar 3. Keterkaitan Konsep Kapasitas, Kompetensi dan Ability (Sumber Fatchiya 2010) 
Masalah mendasar bagi sebagian besar petani di Indonesia khususnya perbatasan adalah ketidakberdayaan dalam negoisasi harga dari hasil pertaniannya. Petani lemah dalam posisi tawar, sehingga menyebabkan pendapatan petani menjadi tidak maksimal. Peningkatan produktivitaspun tidak lagi menjadi jaminan keuntungan bagi petani karena tidak ada kesetaran subsektor hulu hilir. Membangun kesadaran petani terkait kesadaran berkomunitas atau berkelompok atas dasar kesamaan kebutuhan dan bukan karena paksaan, perlu dilakukan dengan tujuan mengorganisasikan kekuatan petani, memperoleh posisi tawar dan informasi pasar, dan memiliki peran dalam menentukan harga produk pertanian.

Oladele dan Tekena (2010) mengatakan bahwa arah program penyuluhan juga harus berorientasi pada pasar sehingga petani tetap kompetitif dan menguntungkan. Lebih lanjut Nasrul (2012) mengatakan bahwa dalam pembangunan pertanian tidak hanya dilihat pada peningkatan capaian produksi sehingga terjadi peningkatan produktivitas usaha tani, sehingga dinilai hanya pada adanya nilai tambah ekonomi saja, namun juga dampak dari berjalannya fungsi kelembagaan petani yang mampu mensinergikan semua elemen sumberdaya dalam pencapaian tujuan bersama. Menurut Umar et al. (2017) peran penyuluh juga berpengaruh sebagai penyampai inovasi ke petani. Fungsi kelembagaan petani merupakan bagian dari pranata sosial yang memfasilitasi interaksi sosial dalam sebuah organisasi (Suradisastra 2008). Fungsi ini sebagai upaya pemberdayaan individu petani dimana akan mempengaruhi keputusan petani dalam adopsi inovasi.
Kemampuan petani dalam mensinergikan kemampuan teknis dan manajerial usahatani, khususnya dalam pembangunan pertanian di perbatasan menjadi tantangan bagi seluruh komponen pembangunan, terutama penyuluh dalam kegiatan penyuluhannya. Mengarahkan petani lahan marginal di perbatasan untuk berorientasi agribisnis dengan memanfaatkan potensi lahan dan sumberdaya alam lainnya memiliki tujuan untuk meningkatkan kesejahteraan petani sehingga terbebas dari kemiskinan dan keterbelakangan dan mampu berkontribusi pada peningkatan produksi dan produktivitas padi menuju Lumbung Pangan Dunia 2045 di perbatasan Indonesia.

\section{KESIMPULAN}

Kapasitas petani merupakan faktor penting dalam pembangunan pertanian. Kapasitas yang tinggi memastikan keberhasilan dan keberlanjutan usahatani. Kemampuan petani dalam memenuhi kebutuhan sesuai dengan potensi yang dimiliki menjadi landasan keberhasilan usahatani. Pendekatan yang menekankan kepada kapasitas diri petani dan kapasitas sumberdaya yang dimiliki petani akan menjamin keberlanjutan adopsi inovasi (pada teknologi pertanian) dan dapat meningkatkan usahatani, sehingga membangun kapasitas petani khususnya di wilayah perbatasan sangat diperlukan agar memiliki daya saing tinggi dalam menghadapi tantangan global.

\section{DAFTAR PUSTAKA}

Afrizal. 2013. Membangun Sumber Daya Manusia Kawasan Perbatasan (Perspektif Pemberdayaan Pemuda) di Provinsi Kepulauan Riau. [Internet]. [diacu 31 Oktober 2018]. 
Tersedia pada : http://riset.umrah. ac.id/wp-content/uploads/2013/10/ MEMBANGUN-SUMBER-DAYA -MANUSIA-KAWASAN-

PERBATASAN-Perspektif-

Pemberdayaan-Pemuda-di-

Provinsi-Kepulauan-Riau.pdf

[BPS] Badan Pusat Statistik. 2013. Berita Resmi Statistik : Hasil Sensus Pertanian 2013 (Angka Tetap) Rumah Tangga Petani Gurem Tahun 2013. BPS No.90/12/Th.XVI, 2 Desember 2013. Jakarta (ID):BPS.

[BPS] Badan Pusat Statistik. 2017. Kabupaten Belu Dalam Angka 2017. Jakarta (ID):BPS.

[BPS] Badan Pusat Statistik. 2018. Berita Resmi Statistik : Profil Kemiskinan di Indonesia Maret 2018. Jakarta (ID):BPS.

[BPPSDMP] Badan Penyuluhan dan Pengembangan SDM Pertanian. 2018. Pedoman Penerapan Pertanian Terpadu. Jakarta (ID) : Kementerian Pertanian.

Dariah A dan Las I. 2010. Ekosistem Lahan Kering Sebagai Pendukung Pembangunan Pertanian, Bab III Buku Membalik Kecenderungan Degradasi Sumber Daya Lahan dan Air. Bogor (ID): IPB Press.

Davis K dan Sulaiman RV. 2014. The New Extensionist : Roles and Capasities to Strengthen Extension and Advisory Services. Journal of International Agricultural and Extension Education Volume 21, Issue 3 doi : 10.5191/jiaee.2014.21301.

Handayani T. 2018. Inovasi Teknologi Mendukung Lumbung Pangan Dunia 2045. Disampaikan dalam Seminar Nasional Riset-riset Terkini dalam rangka Pencapaian Indonesia sebagai Lumbung Pangan Dunia di Solo, 18-19 April 2018.

Irsan R, Muta'ali L, Sudrajat. 2017. Pertumbuhan Bidang Ekonomi di
Perbatasan Indonesia-Malaysia. Prosiding Seminar Nasional Geografi UMS 2017, Pengelolaan Sumber Daya Wilayah Berkelanjutan. ISBN:978-602-361072-3.

Ishaq M, Rumiati AT, Permatasari EO. 2017. Analisis Faktor-faktor yang Mempengaruhi Produksi Padi di Provinsi Jawa Timur Menggunakan Regresi Semiparametrik Spline. Jurnal Sains dan Seni ITS Vol.6, No.1, (2017) ISSN : 2337-3520 (2301-928X Print).

Jaya R. 2017. Laporan Akhir : Dukungan Agro-Inovasi Teknologi di Daerah Perbatasan di Provinsi Aceh. Balai Pengkajian Teknologi Pertanian Aceh, 2017.

[Kementan] Kementerian Pertanian. 2015. Rencana Strategis Kementerian Pertanian Tahun 20152019. Jakarta (ID) : Kementerian Pertanian.

[Kementan] Kementerian Pertanian 2018. Pedoman Penerapan Sistem Pertanian Terpadu. Jakata (ID) : Kementerian Pertanian.

Mahananto, Sutrisno S, Ananda CF. 2009. Faktor-faktor yang mempengaruhi Produksi Padi Studi Kasus di Kecamatan Nogosari, Boyolali, Jawa Tengah. Jurnal Wacana Vol.12 No.1 Januari 2009 ISSN. 1411-0199.

Nasrul W. 2012. Pengembangan Kelembagaan Pertanian untuk Peningkatan Kapasitas Petani terhadap Pembangunan Pertanian. Jurnal Menara Ilmu Volume III No.29, Juni 2012.

Oladele OI dan Tekena SS. 2010. Factors influencing agricultural extension officers'knowledge on practice and marketing of organic agriculture in North West Province, South Africa. Life Science Journal Vol.7 No.3 
September

2010.

Htpp://www/sciencepub.net

[Peraturan BNPP No.1]. 2015. Peraturan tentang Rencana Induk Pengelolaan Perbatasan Negara Tahun 20152019. Jakarta (ID) : Badan Nasional Pengelola Perbatasan RI.

Prasojo ZH. 2013. Dinamika Masyarakat Lokal di Perbatasan. Jurnal Walisongo, Volume 21, Nomor 2, November 2013.

Priyanto D dan Diwyanto K. 2014. Pengembangan Pertanian Wilayah Perbatasan Nusa Tenggara Timur dan Republik Demokrasi Timor Leste. Jurnal Pengembangan $\begin{array}{lll}\text { Inovasi Pertanian } & \text { Vol.7 No.4 }\end{array}$ Desember 2014:207-220.

Saheb, Slamet Y, Zuber A. 2013. Peranan Modal Sosial Bagi Petani Miskin Untuk Mempertahankan Kelangsungan Hidup Rumah Tangga di Pedesaan Ngawi (Studi Kasus di Desa Randusongo Kecamatan Gerih Kabupaten Ngawi Provinsi Jawa Timur). Jurnal Analisa Sosiologi Oktober 2013, 2 (1) : 17-34.

Saleh MH. 2015. Dinamika Masyarakat Perbatasan (Eksistensi Perantau Bugis di Pulau Sebatik Kalimantan Utara : Perspektif Cultural Studies). Jurnal Borneo Administrator/Volume 11/No.1/2015.

Saragih R, Kustiawan, Afrizal. 2016. Pembangunan Sumber Daya Manusia Pada Wilayah Perbatasan Kabupaten Bintan (Studi pada Lembaga Pemberdayaan Masyarakat Desa Berakit Kabupaten Bintan Tahun 2016. [Internet]. [diacu 31 Oktober 2018]. Tersedia dari http://repository.umrah.ac.id/704/1/ jurnal\%20riandi\%202.pdf

Saragih B. 2017. Tantangan Masyarakat Perbatasan Indonesia dalam
Integrasi Asean. Paper disampaikan ke Ditjen Kerjasama ASEAN untuk Konferensi Bersama Sekretariat Nasional Asean-Indonesia dan PSA di Jakarta 30 Agustus 2017.

[SKRI] Sekretariat Kabinet Republik Indonesia. 2015. Urgensi Ketahanan Pangan. [Internet].[diacu 20 Oktober 2018]. Tersedia dari : http://setkab.go.id/urgensiketahanan-pangan/

Sulaiman A, Simatupang P, Las I, Jamal E, Hermanto, Kariyasa IK, Syahyuti, Sumaryanto S, Suwandi, Subagyono K. 2017. Sukses Swasembada Indonesia Menjadi Lumbung Pangan Dunia 2045. Jakarta (ID) : Kementerian Pertanian.

Suradisastra, Kedi. 2008. Strategi Pemberdayaan Kelembagaan Petani. Forum Penelitian Agro Ekonomi, Volume 26 No.2, Desember 2008 : 82-91.

Umar S, Man N, Nawi NM, Latif IA, Samah BA. 2017. Core Competency Requirement Among Extension Workers In Penisular Malaysia: Use of Borich's Needs Assessment Model. Evaluation and Program Planning $62 \quad$ (2017) 9-14. http://dx.doi.org/10.1016/j.evalprog plan.2017.02.011

[UU No.16]. 2006. Undang-undang Sistem Penyuluhan Pertanian, Perikanan dan Kehutanan No.16 Tahun 2006. Jakarta (ID) : Presiden RI

[UU No.43]. 2008. Undang-undang tentang Wilayah Negara. Jakarta (ID) : Presiden RI. 